\title{
Learning Style Preferences Among Medical Students in Malaysian Medical Universities
}

\author{
Roy Rillera Marzo ${ }^{1}$, Thilagarani M. ${ }^{2}$, Maniarasi M. ${ }^{2}$ \\ ${ }^{1}$ Deputy Dean, Asia Metropolitan University, Master in Public Health, Fellow in \\ Public Health \\ ${ }^{2}$ MBBS, Asia Metropolitan University \\ Email:-rrmtexas@yahoo.com
}

\begin{abstract}
Introduction: Medicals students are being exposed to different learning environments, at the same time receiving vast extents of information. The information on learning style can also benefit the students by helping them to formulate appropriate learning strategies to enhance their learning. VARK is a questionnaire that determines a person's sensory modality preferences.

Aim: The aim of this study is to identify the learning style preference among medical students in Malaysian medical universities.

Methodology: A descriptive cross sectional study was done in 2015. Convenience sampling was used to choose the sample population. Sample size was 239 students. VARK ${ }^{\complement}$ questionnaire Version 7.8 was used to assess the learning style among preclinical and clinical medical students from three medical universities in Malaysia. Questionnaire was distributed among students in the form of hard copy after taking an informed consent.

Results: Majority (53.61\%) out of 97 preclinical students preferred unimodal learning style. $46.39 \%$ out of 142 clinical students had highest preference towards multimodal learning style. Kinesthetic was the mode of choice from the VARK component for both preclinical and clinical students. In multimodal learning style, trimodal and bimodal mode was preferred by preclinical and clinical students respectively.

Conclusion: Kinesthetic modality is the strongest single preference for both preclinical and clinical students. Preclinical students preferred unimodal learning style and clinical students preferred multimodal learning style.
\end{abstract}

Keywords: VARK, learning style, preclinical and clinical, gender, ethnicity

\section{Introduction}

The first school of medicine of medieval times came into existence, probably in the ninth century, on the shores of the Tyrrhenian Sea, in the town of Salerno. (Fulton, 1953 , p. 458). Since then, learning medicine has evolved from method of rational inquiry to apprenticeship training to pedagogy (teacher-centred learning) and recently to andragogy (student-centred learning).

According to AAMC resources based on recent research, less than $15 \%$ of students dreaming about becoming a doctor will succeed. One of the reasons medical students dropout of medical school is the in sufficient academic capacity. Currently, various instructional methods are being implemented in medical education. These includes lectures, tutorials, seminar, self directed learning and practicals. Medicals students are being exposed to different learning environments, at the same time receiving vast extents of information.

Each students may have their own preferences in receiving and processing informations. Thus, acquiring knowledge on students learning style is important to provide students with satisfactory learning experience. The information on learning style can also benefit the students by helping them to formulate appropriate learning strategies to enhance their learning. (Kharb P., Samanta P. P., Jindal M., Singh V., 2013) 
Stewart K. L. and Felicetti L. A. (1992) define learning style as "those education conditions under which a student is most likely to learn". Back in year 1979, James W. Keefe expressed learning style as "characteristics cognitive, affective and psychological behaviours that serves as relatively stable indicators of how learners perceive, interact with, and respond to the learning environment.

Student learning styles or preferences are influenced by many factors including gender, age, academic achievement, brain processing, culture and creative thinking. (Honigsfeld A., 2001).

There have been various modals developed to explain different learning styles including Kolb's Learning Inventory and Gardner's Multiple Intelligence Theory.(Khanal L., Shah S., Koirala S., 2013). VARK (an acronym for Visual, Aural, $\mathrm{Read} /$ write and Kinesthetic preference modalities), is a questionnaire that determines a person's sensory modality preferences.(Marcy V., 2005). This inventory was developed by Neil D. Fleming, a teacher New Zealand in 1987.

Visual (V) learners prefers using images, pictures, illustrations, colors and maps to process information. Aural (A) learners depends on information that is heard or spoken as a way of learning. Thus, they like to listen to lectures, attend tutorials, involve in discussions and use tape records. Read/Write (R) learners prefers to use of printed word to convey and receive information. They like to read textbooks, handouts, and notes. Kinesthetic (K) learners prefers getting information through experiences and convention. They would love hands-on approaches, field trips and laboratories activities.

Although, learners can use all of the four $(\mathrm{V}, \mathrm{A}, \mathrm{R}, \mathrm{K})$ sensory mode of learning, one mode is often dominant and preferred.(Muralidhara D. V., Simbak N., Nor M. N. M., 2013). According to individual preference to learning style, learners can be classified as unimodal if they show predominantly one learning preference or multimodal if preference is shared between 2 or more learning styles. (Samarakoom L., Fernando T., Rodrigo C., Rajapakse S., 2013).

Davis BG (2009) stated that recent research indicates that students' learning styles and approaches to study may have a significant bearing on the academic success.

Some studies suggested that knowing about their preferred learning style assist students to improving their learning. There was less agreement among students that knowing their learning style helped their performance in exams.(Breckler J., Joun D., and Ngo H., 2009; Kumar L. R. \& Chacko T. V., 2012).

This review focus on the predominant preferred learning styles in preclinical and clinical medical students in Malaysia. The conclusion might be used to cater medical student according to their preference in preclinical and clinical years respectively.

\section{Literature review}

Despite many critics from renowned researchers and scholars, numerous studies on learning styles are being conducted in various countries in past decades. These studies are also being conducted among medical students. The conclusion from those studies are being used to derive teaching-learning strategies for a better learning experience. Certain studies correlates the learning styles of students to their academic performance, to their age and to their gender.

Khalil et al. conducted a studies among 133 Dubai Medical College preclinical and clinical students. This study showed that both preclinical and clinical students have multimodal learning style preference $(75 \%$ preclinical students and $61 \%$ clinical students). The remaining (25\% preclinical students and $39 \%$ clinical students) preferred unimodal learning style. Both preclinical and clinical student preferred kinesthetic mode from unimodal learning style with respective of $43.50 \%$ and 61.50\%. (Khalil M. M., Ahmed, Gawish S. M., 2008). 
A study by Baykan Z. and Nacar M. in 2006 involving 155 first year medical students from Turkey shows that $63.9 \%$ of the students preferred multimodal learning styles. Among those students bimodal was dominant over trimodal and quadmodal with $47.42 \%$. Out of $36.1 \%$ of student who preferred unimodal learning, kinesthetic mode of learning style was the most common with $64.54 \%$ preference. This was concurrent with the study that was done by Lujan in USA among 166 first year medical student that showed dominant of multimodal learning styles with $63.80 \%$. These findings were also comparable with the study done by Kharb et al. in India. (Baykan Z., Nacar M., 2006; Lujan H. L., Dicarlo S. E., 2005; Khrab P. et al., 2013).

Contradicting to most of the studies, the result from a study by Johnson M. in Indiana, USA showed majority preference of unimodal learning styles. $58.10 \%$ out of 74 first year students showed unimodal preference and $41.89 \%$ showed multimodal preference. The most prevalent mode among unimodal learners is read-write (39.50\%), followed by kinesthetic (38.50\%), visual (16.27\%) and aural $(9.30 \%)$. Another study by Patil et al. in Maharashthra, India also showed unimodal learning style preference. (Johnson M., 2009; Patil N. P., Bhise S. V., 2014).

However, there are some studies which showed nearly equal preference for unimodal and multimodal learning style. In a study by Shankar et al in Netherlands among 91 premedical and medical students showed unimodal preference of $47.20 \%$ and multimodal preference of $52.70 \%$. A study in Saudi Arabia by Almigbal T. H. among 600 King Saud University's medical students showed very little difference between unimodal and multimodal learning style preference. The unimodal preference were $53.39 \%$ and the multimodal preference were $46.30 \%$. (Shankar P. R., Balasubramanium R., Dwivedi N. R., Ramireddy R., Barton B., 2014; Almigbal T. H., 2015).

Sinha et al. conducted a study among the clinical students of Melaka-Manipal Medical college in 2012. Majority (56\%) of their students have multimodal learning style. Bimodal (50\%) was dominant in this category, followed by trimodal $(33.92 \%)$ and quadmodal (16.07\%). The remaining $44 \%$ preferred unimodal learning style. The stronger unimodal preference was kinesthetic (45.45\%). Similar result were obtain in the study done by Mon et al. in SEGi University with 98 preclinical students. (Sinha N. K., Bhardwaj A., Singh S., Abas A. L., 2012; Mon A. A., Fatini A., Ye C. W. Barakat M. A., Jen P. L., Lin T. K., 2013).

Another study in Malaysia by Muralidhara et al. showed a vast difference between the unimodal and multimodal preference. Among 82 preclinical students who participated in the study, only $15.90 \%$ showed unimodal preference. Out of that, $38.36 \%$ have read-write preference. Both aural and kinesthetic mode have equal preference which is $30.82 \%$. Out of $84.10 \%$ of multimodal learning style, quadmodal $(87.04 \%)$ have strongest preference. (Muralidhara D. V., Simbak N., Nor M. N. M., 2013).

However, study by Liew et al. in International Medical University, Malaysia showed unimodal prefernce. Out of 470 students involved, a vast majority of $81.90 \%$ showed unimodal preference and remaining $18.10 \%$ showed multimodal preference. However, this study did not go further in identifying the specific mode among unimodal and multimodal learning styles. (Liew S. C., Sidhu J., Barua A., 2015).

After exhaustive review of previously done studies, it is found that there is always an inconsistency in the finding. This may be caused by many factors including demographic factors and the variation in the curriculum applied in different medical school. In addition, there is little known about the learning style among the preclinical and clinical medical students in Malaysia. Thus, current study will be conducted to identify the preferred learning style among preclinical and clinical students in Malaysian medical universities. 
South American Journal of Public Health

Volume 4, Issue 1, 2016

\section{Methodology}

A cross sectional study was carried out in three medical colleges of Malaysia in November and December 2015.

\section{Settings}

The study was conducted in Masterskill University College of Healthsciences, Cyberjya University College of Healthsciences and Mahsa University.

\section{Participants}

239 volunteers from first year students to fifth years students from respective colleges were involved in this study.

\section{Survey Instrument}

Printed version of a validated VARK $^{\odot}$ questionnaire version 7.8 was used to determine the learning style preferences among medical students.

\section{Questionnaire Design}

VARK $^{\odot}$ questionnaire version 7.8 consists of 16 questions with four options each. It was attached with few others questions requiring participants personal and demographic data. Respondents may choose more than one option to determine the category of their learning style.

\section{Research procedure}

Students were explained about the purpose of the study. They were briefed on how to answer the questions. Questionnaire was distributed to each students after getting their informed consent. Students were given enough time to fill up the form. Completed questionnaire was collected from the students.

\section{Data Analysis Procedures}

First, the data will be coded and interpreted by SPSS version 18. Data analysis including descriptive statistic will be used to describe participants demographic characteristics, tables and charts will be used to present the results.

\section{Ethical Consideration}

Medical Research and Ethics Committee of Masterskill University College of Health had reviewed the protocol and insured full protection of the rights of the study.

\section{Results}

Table 1 shows the mean and standard deviation for each VARK component among preclinical and clinical students. It clearly shows that kinesthetic mode have the highest mean $(\approx 6)$ for both preclinical and clinical students.

Table 1. Mean and standard deviation of each VARK ${ }^{\odot}$ component

\begin{tabular}{|l|l|l|l|l|l|}
\hline \multicolumn{2}{|c|}{ Phase } & Visual & Aural & Kinesthetic & Read \\
\hline \multirow{5}{*}{ Preclinical } & Mean & 4.1237 & 4.4536 & 6.3402 & 4.1340 \\
\cline { 2 - 6 } & $\begin{array}{l}\text { Std. } \\
\text { Deviation }\end{array}$ & 2.94483 & 2.71577 & 2.63346 & 2.40931 \\
\hline Clinical & Mean & 4.4648 & 5.0141 & 6.9014 & 4.3944 \\
\cline { 2 - 6 } & $\begin{array}{l}\text { Std. } \\
\text { Total }\end{array}$ & 2.59749 & 2.89285 & 2.86656 & 2.50094 \\
& Deviation & 4.3264 & 4.7866 & 6.6736 & 4.2887 \\
\cline { 2 - 6 } & $\begin{array}{l}\text { Std. } \\
\text { Deviation }\end{array}$ & 2.74286 & 2.83000 & 2.78241 & 2.46239 \\
\hline
\end{tabular}


Figure 1 shows that out of 97 preclinical students, 53.61\% (52) students had unimodal preference and $46.39 \%$ (45) students had multimodal preference. $45.07 \%$ (64) of 142 clinical students had unimodal preference and remaining $54.93 \%$ had multimodal preference.

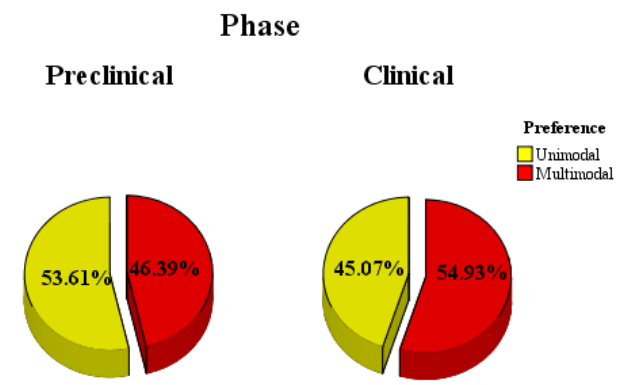

Figure 1. Learning style preference among preclinical and clinical students

Further analysis showed that kinesthetic mode was the predominant unimodal learning styles among both preclinical and clinical students with $69.2 \%$ (36) and $59.4 \%(38)$ respectively.

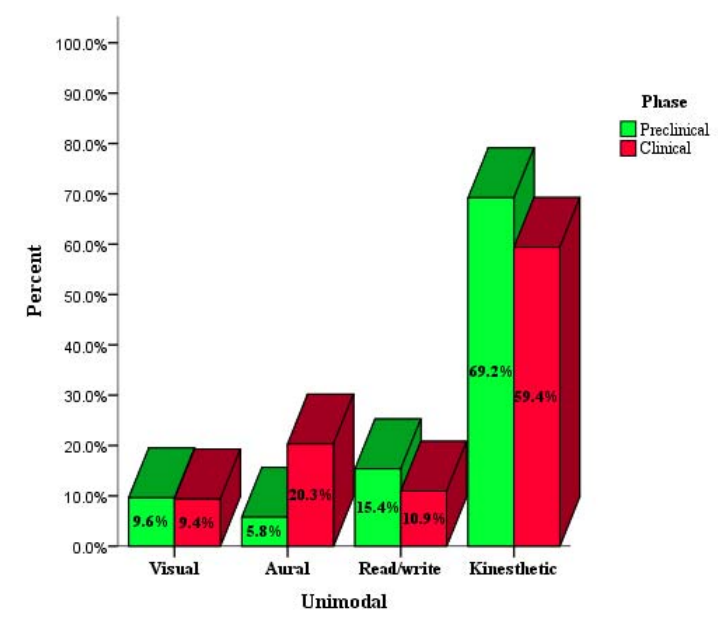

Figure 2. Unimodal distribution among preclinical and clinical students

Figure 3 shows that among multimodal learning style, preclinical students had higher preference for trimodal mode $(44.4 \%)$ and clinical students preferred bimodal mode $(52.6 \%)$. 
South American Journal of Public Health

Volume 4, Issue 1, 2016

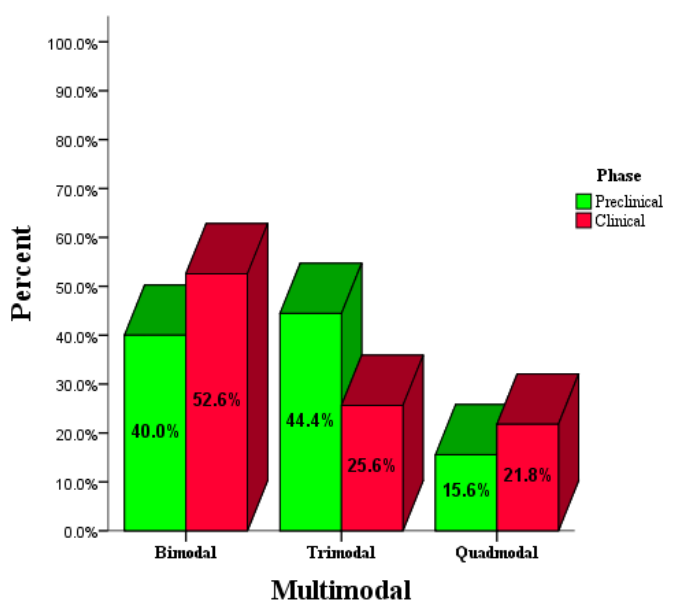

Figure 3. Multimodal distribution among preclinical and clinical students

Table 2 shows the comparison of learning style preference of female and male students. It was observed that, 43 (48.86\%) male students preferred unimodal learning style and the rest preferred multimodal learning style. Similarly, $48.34 \%$ of female students had unimodal preference and $51.66 \%$ female students preferred multimodal learning style.

Table 2. Learning style preference among male and female students

\begin{tabular}{|c|c|c|c|c|c|}
\hline & \multicolumn{2}{|c|}{ Preference } & \multirow{2}{*}{ Total } \\
\hline & & & Unimodal & Multimodal & \\
\hline \multirow{4}{*}{ Gender } & \multirow{2}{*}{ Male } & $\mathrm{N}$ & 43 & 45 & \multirow{2}{*}{88} \\
\hline & & $\%$ & $48.9 \%$ & $51.1 \%$ & \\
\hline & \multirow{2}{*}{ Female } & $\mathrm{N}$ & 73 & 78 & \multirow{2}{*}{151} \\
\hline & & $\%$ & $48.3 \%$ & $51.7 \%$ & \\
\hline \multicolumn{3}{|c|}{ Total } & 116 & 123 & 239 \\
\hline
\end{tabular}

Table 3 emphasizes on the unimodal learning style distribution among male and female students. Male students registered highest preference for kinesthetic mode (72.1\%) followed by visual, aural and read/write. Female students preferred kinesthetic mode (58.9\%) above read/write, aural and visual.

Table 3. Unimodal distribution among male and female students

\begin{tabular}{|c|c|c|c|c|c|c|c|}
\hline & \multicolumn{4}{|c|}{ Unimodal } & \multirow{2}{*}{ Total } \\
\hline & & & Visual & Aural & Read/Write & Kinesthetic & \\
\hline \multirow{4}{*}{ Gender } & \multirow{2}{*}{ Male } & $\mathrm{N}$ & 5 & 5 & 2 & 31 & \multirow{2}{*}{43} \\
\hline & & $\%$ & $11.6 \%$ & $11.6 \%$ & $4.7 \%$ & $72.1 \%$ & \\
\hline & \multirow{2}{*}{ Female } & $\mathrm{N}$ & 6 & 11 & 13 & 43 & \multirow{2}{*}{73} \\
\hline & & $\%$ & $8.2 \%$ & $15.1 \%$ & $17.8 \%$ & $58.9 \%$ & \\
\hline & \multicolumn{2}{|l|}{ Total } & 11 & 16 & 15 & 74 & 116 \\
\hline
\end{tabular}

Table 4 shows the distribution of multimodal learning style among male and female students. It shows that male students preferred mode and female students preferred mode. 
Table 4. Multimodal distribution among male and female students

\begin{tabular}{|c|c|c|c|c|c|c|}
\hline & \multicolumn{3}{|c|}{ Multimodal } & \multirow[b]{2}{*}{ Total } \\
\hline & & & Bimodal & $\begin{array}{l}\text { Trimod } \\
\text { al }\end{array}$ & $\begin{array}{l}\text { Quadmoda } \\
\text { d }\end{array}$ & \\
\hline \multirow{4}{*}{ Gender } & \multirow{2}{*}{ Male } & $\mathrm{N}$ & 19 & 15 & 11 & \multirow{2}{*}{45} \\
\hline & & $\%$ & $42.2 \%$ & $33.3 \%$ & $24.4 \%$ & \\
\hline & \multirow{2}{*}{ Female } & $\mathrm{N}$ & 40 & 25 & 13 & \multirow{2}{*}{78} \\
\hline & & $\%$ & $51.3 \%$ & $32.1 \%$ & $16.7 \%$ & \\
\hline & \multicolumn{2}{|l|}{ Total } & 59 & 40 & 24 & 123 \\
\hline
\end{tabular}

Figure 4 shows preferred learning style among different ethnic group involved in this study. There was no much significant in the relation of ethnicity to the learning style preference. Except for the Chinese, the rest have multimodal learning style preference.

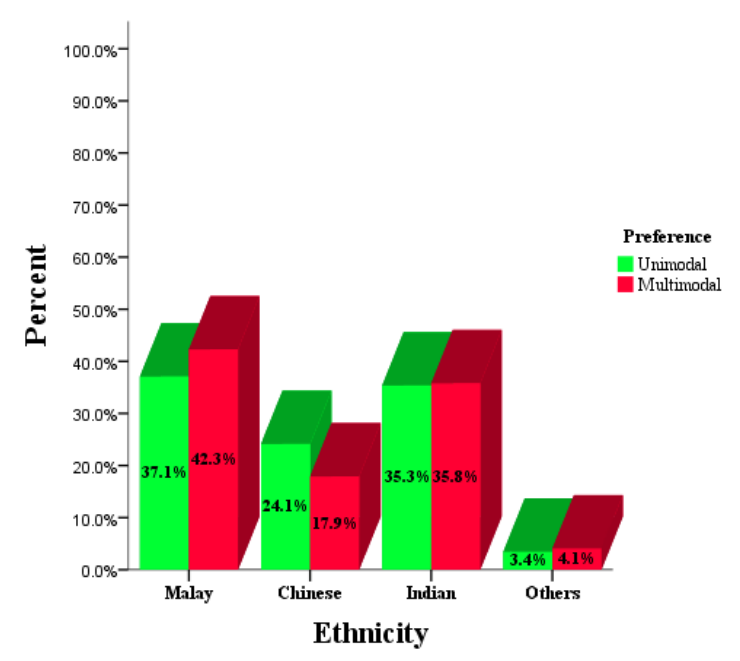

Figure 4. Learning style preference among different ethnic group

\section{Discussions}

Medical program is divided into two phases (preclinical \& clinical). The theoretical knowledge which is obtained in the preclinical years has to be implemented practically in their clinical years. Therefore, in this study VARK@ questionnaire was administered to identify the predominant learning style preference among preclinical and clinical students.

It was found that preclinical students preferred unimodal (53.61\%) above multimodal $(46.39 \%)$ learning style. This corresponds to the studies done by Johnson M., Wehrwein et al, Almigbal T. H. and Patil et al. but opposes the study Samarakoon et al. Out of unimodal distribution among preclinical students, kinesthetic mode (69.2\%) has the highest preference followed by read/write, visual and aural. Similar result was produced in study done by Saadi et al in Saudi Arabia. This indicates that medical students prefer to perceive information through practical sessions. In multimodal learning category, preclinical students preferred trimodal mode (44.4\%), over bimodal and quadmodal. Our study of multimodal preference among preclinical students are in agreement with the study done by Nuzhat et al., and Singh et al.).

In contrast with preclinical student, clinical students have higher preference towards the multimodal (54.93\%) learning style which is in line with Samarakoon et al. However, it is interesting to know that kinesthetic $(59.4 \%)$ is still the mode of choice in unimodal category leaving behind aural, read/write and visual modes. 
Regarding the multimodal learning style, it is in contrast with preclinical students where clinical students preferred bimodal (52.6\%) above trimodal and quadmodal. This was consistent with study done by Sinha et al. Which involved 176 clinical students in Malaysia.

In our study, both male and female showed similar level of preference $(51.5 \%$ male and $51.7 \%$ female) for multimodal learning style. This result was in accordance with few other studies (Slater et al., Shah et al. and Mon et al.). Even the multimodal distribution showed similar pattern for both gender. Significantly, kinesthetic mode is the most preferred for both male and female students, though there is slight variation between other modes. This result was in conformity with studies by Slater et al. and Saadi et al. Female students preferred read/write mode second to kinesthetic while male students have equal preference toward visual and aural second to kinesthetic.

Learning style preferences among different ethnic group showed that Malay, Indian and Others category show predominant preference towards multimodal learning style except for Chinese which exhibit unimodal learning style preference.

\section{Conclusion}

According to this study, there is a variation in learning style preference among preclinical and clinical students. Thus, this information can be used to cater the need of constructing strategical learning-teaching instruction for the medical students. However, analysis of learning style preference among both gender showed no significant difference observed. Among all the ethnic group, Chinese students clearly showed unimodal preference whereas other ethnic group have multimodal preference.

\section{Recommendation}

The information about students learning style can be use to develop a potentially useful learning strategies for medical students. Correlations between students learning style preferences and instructional need can aid lecturers or educators in formulating teaching-learning instructions. It is important for the medical universities to identify students learning style preference in the beginning. Curriculum in medical school can be prepared in accordance to students learning preferences. Discussion session can be conducted between lecturers and students to come up with appropriate teachinglearning instructions. The data from this study showed that kinesthetic was the most preferred mode of learning among both preclinical and clinical. Thus, more hands on approach such as role playing, use of models, performing procedure and learning physical examination will be in favor of medical students. It will help to refine the study of medicine into something more fascinating. This will concomitantly help students to develop more enthusiasm towards the subject, enhance the learning process and perform better.

\section{References}

[1]. Almigbal, T. H. (2015). Relationship between the learning style preferences of medical students and academic achievement. Saudi Medical Journal, 36(3), 349-355. doi: 10.15537/smj.2015.3.10320.

[2]. Anu, S., Anuradha, \& Meena, T. (2012). Assessment of learning style preference among undergraduate medical students-using VAK assessment tool. International Journal of Medical and Clinical Research, 3(8), 229231. doi:10.9735/0976-5530.3.8.229-231.

[3]. Bataduwaarachchi, V. R., Dissanayake, M. M., Thillainathan, \& S., Jayasekara, R. W. (2013). Perception of the learning strategies and the learning styles among first year medical students:A cross sectional study. SouthEast Asian Journal of Medical Education, 7(1), 14-21. Retrieved from http://seajme.md.chula.ac.th/articleVol7No1/OR2_Vipula.pdf.

[4]. Baykan, Z. \& Nacar, M. (2007). Learning styles of first-year medical students attending Erciyes University in Kayseri, Turkey. Advances in Physiology Education, 31, 158-160. doi:10.1152/advan.00043.2006. 
[5]. Breckler, J., Joun, D., \& Ngo, H. (2009). Learning styles of physiology students interested in the health professions. Advances in Physiology Education, 33(1), 30-36 (PMID;19261758) doi:0.1152/advan.90118.2008.

[6]. Choudhary, R., Dullo, P., \& Tandon, T. V. (2011). Gender differences in learning style preferences of first year medical students. Pakistan Journal of Physiology, 7(2), 42-45. Retrieved from http://www.pps.org.pk/PJP/72/Raghuveer.pdf.

[7]. Daud, S., Kashif, R., \& Chaudhry, A. M. (2014). Learning styles of medical students. South East Asian Journal of Medical Education, 8(1), 40-46. Retrieved from https://wwwacademia.edu/9876593/Learning_Styles_of_Medical_Education.

[8]. Davis, B. G. (2009). Tools for Teaching. 2nd ed. San Francisco: Jossey-Bass.

[9]. Dey, C. K., Pande, S. R., Kaundinya, S. D., \& Sinha, S. (2015). Assessment of effect of gender on learning style preferences among first year medical students. International Journal of Scientific Study, 3(2), 73-78. doi:10.17354/ijss/2015/217.

[10]. Dobson, J. L. (2009). Learning style preferences and course performance in an undergraduate physiologyclass. American Journal of Physiology, 33, 308-314.doi:10.1152/advan. 00048.2009.

[11]. Dobson, J. L. (2010). A comparison between learning style preferences and sex, status and course performance. American Journal of Physiology, 33.308-314. doi:10.1152/advan.00078.2010.

[12]. El Tantawi, M. M. (2009). Factors affecting postgraduate dental students' performance in a biostatics and research design course. Journal of Dental Education, 73(5), 614-623. Retrieved from http://www.jdentaled.org/content/73/5/614.full.pdf+html.

[13]. Fulton, J. F. (1953). History of Medical Education. British Medical Journal, 2(4834), 457-461. Retrieved from http://www.ncbi.nlm.nih.gov/pmc/articles/PMC2029428/.

[14]. Honigsfeld, A. (2001). A comparative analysis of the learning styles of adolescents from diverse nations by age, gender, academic achievement level and nationality. The Humanities and Social Sciences, 62, 696

[15]. Johnson, M. (2009). Evaluation of learning style for first year medical students. International Journal for Scholarship of Teaching and Learning, 3(1), 1-15. Retrieved from http://digitalcommons.georgiasouthern.edu/cgi/viewcontent.cgi?article=1149\&context=ij-sotl.

[16]. Khalid, A., Rahim, K., Bashir, Z., \& Hanif, A. (2015). Learning Style Preferences Among Students of Medical and Dental Colleges. Advances in Health Professions Education, 1(1), 13-17.Retrieved from http://ahpe.kmu.edu.pk/article/view/13.

[17]. Khalil, M. M., Ahmed, Gawish, S. M. (2014).Towards better understanding of medical students: learning styles of preclinical and clinical medical students. South East Asian Journal of Medical Education, 8(2), 2028.Retrieved from http://seajme.md.chula.ac.th/articleVo18No2/5_OR2_Khalil.pdf.

[18]. Khanal, L., Shah, S., Koirala, S. (2014). Exploration of preferred learning styles in medical educations using VARK modal. Russian Open Medical Journal, 3: 0305, 1-8. doi: 10.15275/rusomj.2014.0305.

[19]. Kharb, P., Samanta, P. P., Jindal M., \& Singh V. (2013). The Learning Styles and the Preferred TeachingLearning Strategies of First Year Medical Students. Journal of Clinical and Diagnostic Research, 7, 1089-1092. doi: $10.7860 /$ JCDR/2013/5809.3090.

[20]. Kumar, L. R., \& Chacko, T. V. (2012). Using appreciative inquiry to help students identify strategies to overcome handicaps of their learning styles. Education for Health, 25(3), 160-164 (PMID;23823635). doi: 10.4103/1357-6283.109794.

[21]. Liew, S. C., Sidhu, J., \& Barua, A. (2015). The relationship between learning preferences (styles and approaches) and learning outcomes among pre-clinical undergraduate medical students. BMC Medical Education, 15, 44. doi:10.1186/s12909-015-0327-0.

[22]. Lujan, H. L., \& Dicarlo, S. E. (2015). First-year medical students prefer multiple learning styles. Advances in Physiology Education, 30, 13-16.doi: 10.1152/advan.00045.2005.

[23]. Marcy, V. (2001). Adult Learning Styles: How the VARK@ learning style inventory can be used to improve student learning. Journal of the Association of Physician Assist Programs, 12(2), 1-5. Retrieved from http://varkearn.com/wpcontent/uploads/2014/08/VanessaMarcy.pdf.

[24]. Mon, A. A., Fatini, A., Ye, C. W., Barakat, M. A., Jen, P. L., \& Lin, T.K.(2013). Learning style preferences among pre-clinical medical students. Journal of Medical and Allied Sciences, 4(1), 22-27. Retrieved from http://jmas.in/Vol4Issue1/Learning\%20style\%20preferences\%20among\%20preclinical\%20medical\%20students.p df. 


\section{South American Journal of Public Health}

\section{Volume 4, Issue 1, 2016}

[25]. Muralidhara, D. V., Simbak, N., \& Nor, M. N. M. (2013). Learning style preferences of preclinical medical students in Malaysian University. South-East Asian Journal of Medical Education, 7(1), 22-30. Retrieved from http://seajme.md.chula.ac.th/articleVol7No1/OR_muralidhara.pdf.

[26]. Murphy, R. J., Gray, S. A., Straja, S. R., \& Bogert, M. C. (2004). Student Learning Preferences and Teaching Implications. Journal of Dental Education, 68(8), 859-866. Retrieved from http://www.jdentaled.org/content/68/8/859.full.pdf+html.

[27]. Nayak, V. J., Kamath, A. S., Begum, S., \& Yenni, V. V. (2015). Do We Need to Teach Every Batch of Students Differently? A VARK Profile Study. European Journal of Pharmaceutical and Medical Research, 2(4), 733-740. Retrieved from http://www.ejpmr.com/admin/assets/article_issue/1436954943.pdf.

[28]. Nuzhat, A., Salem, R. O., Quadri, M. S. A., \& Al-Hamdan, N. (2011).Learning style preferences of medical students: a single-institute experience from Saudi Arabia. International Journal of Medical Education, 2, 70 73.doi:10.5116/ijme.4e36.d31c.

[29]. Patil, N. P., \& Bhise, S. V. (2015). Learning styles among first year medical students at S.R.T.R. Government Medical College, Ambajogai, India. International Journal of Anatomy and Research, 3(1), 841-44. doi: 110.16965./ijar. 2014.561.

[30]. Peyman, H., Sadeghifar, J., Khajavikhan, J., Yasemi, M., Rasool, M., Yaghoubi, Y.M.,. Karim, H. (2014). Using VARK approach for assessing preferred learning styles in first year medical sciences students:A survey from Iran. Journal of Clinical and Diagnostic Research, 8(8), 1-4. doi:10.7860/JCDR/2014/8089.4667.

[31]. Prabha, V., Geetha, K. B., Doddamani, B. R., Prakash, M., \& Prakash, S. M. (2013). Learning styles among the first year medical students. International Journal of Pharmaceutical and Biomedical Research, 4(2), 135-139. Retrieved from https:/www.yumpu.com/en/document/view/44059301/learning-styles-among-the-first-yearmedical-students-international.

[32]. Saadi, I. A. (2014). Gender And Learning Styles In Saudi Arabia Schools. The Clute Institute International Academic Conference. Retrieved from http://cluteinstitute.com/conferenceroceedings/2014SAPapers/Article\%20257.pdf.

[33]. Samarakoon, L., Fernando, T., Rodrigo, C., \& Rajapakse S. (2013). Learning styles and approaches to learning among medical undergraduates and postgrauates. BMC Medical Education, 13:42, 1-6. Retrieved from http://www.biomedcentral.com/1472-6920/13/42.

[34]. Sankhla, M., \& Garg, A. (2015). Learning style preferences of first year medical and allied sciences students at Mahatma Gandhi Medical College and Hospital, Jaipur. Scholars Journal of Applied Medical Sciences, 3(5D), 2046-2051. Retrieved from http://saspublisher.com/wpcontent/uploads/2015/08/SJAMS-35D2046-2051.pdf.

[35]. Sarabi-Asiabar, A., Jafari, M., Sadeghifar, J., Tofighi, S., Zaboli, R., Peyman, H., Shams, L. (2014). The relationship between learning style preference, gender and academic major and status in first year medical students: A survey study from Iran. Iran Red Crescent Medical Journal, 17(1):e18250. doi:10.5812/ircmj.18250.

[36]. Shah, C., Joshi, N., Mehta, H. B., \& Gokhle, P. A. (2011). Learning styles adopted by medical students. International Research Journal of Pharmacy, 2(12), 227-229. Retrieved from http://www.irjponline.com/admin/php/uploads/762_pdf.pdf.

[37]. Shankar, P. R., Balasubramanium, R., Dwivedi, N. R., Ramireddy, R., \& Barton, B. (2014). Learning styles of premedical and basic science undergraduate medical students in a Caribbean Medical School. Education in Medicine Journal, 6(4), 58-62. doi:10.5959/eimj.v6i3.250.

[38]. Shenoy, N., Shenoy, K. A., \& Ratnakar, U. P.(2013). The perceptual preferences in learning among dental students in clinical subjects. Journal of Clinical and Diagnostic Research, 7(8), 16831685.doi:10.7860/JCDR/2013/4940.3219.

[39]. Shetty, S. B., Shetty, B. A., Nayanatara, A. K., Pai, S. R., Kini, R. D., Bhagyalaksmi, K., Sahiti Kolluru. (2015). Learning patterns among medical students. International Journal of Current Research, 7(3), 13390-13393. Retrieved from http://www.iosrjournals.org/iosrjrme/papers/Vol-4\%20Issue1/Version-5/G04154351.pdf.

[40]. Singh, M., Garg, R., Behera, B. K., Madan, H., Kaur, J., \& Kaur M. (2014). Learning style preferences of first year MBBS girl students. Transworld Medical Journal, 2(1), 18-23. Retrieved from http://www.tmjournals.com/pdf/Learning\%20style\%20preferences\%20of\%20first $\% 20$ year\%20MBBS\%20girl\%20 students.pdf.

[41]. Sinha, N. K., Bhardwaj, A., Singh, S., \& Abas, A. L. (2013). Learning preferences of clinical students:A study in a Malaysian medical college. International Journal of Medicine and Public Health, 3(1), 660- 63. doi:10.4103/2230-8598-1109325 
South American Journal of Public Health

Volume 4, Issue 1, 2016

[42]. Slater, J. A., Lujan, H. L., \& DiCarlo, S. E.(2007). Does gender influence learning style preferences of firstyear medical students?. Advances in Physiology Education, 31, 336-342. doi:10.1152/advan.00010.2007.

[43]. Ubah, J. N. (2002). Learning Styles among Medical Students, a Case Study of Ladoke Akintola University of Technology Medical School, Osogbo, Western Nigeria. Journal of Education and Practice, 3(5). Retrieved from http://www.iiste.org/Journals/index.php/JEP/article/view/1498/1430. 